Author version: J. Asian Earth Sci., vol.37(4); 2010; 394-398

\title{
Dynamics of formation of ferromanganese nodules in the Indian Ocean
}

\author{
Ranadhir Mukhopadhyay ${ }^{1 *}$, Anil K Ghosh ${ }^{2}$ \\ ${ }^{1}$ National Institute of Oceanography (CSIR), Dona Paula 403004, Goa, India. \\ * Corresponding Author: ranadhir@,nio.org \\ ${ }^{2}$ Department of Geology, University of Calcutta, Kolkata 700019, India. anilgeol@yahoo.co.in
}

\begin{abstract}
The ferromanganese nodule resources of the Indian Ocean Nodule Field (IONF) are second only in the world in terms of metal content and abundance. Since it was made known by Mero (1965) that several trillion tonnes of manganese nodules lay in the world oceans, extensive exploration for nodules has been undertaken during the last four decades. The possibility of harvesting an inexhaustible supply of nodules from oceans has resulted in formulation of several national and international programs. India started her search for ferromanganese nodules in 1982.

The investigations have resulted in a comprehensive assessment of manganese nodule resources at the ocean-level, and on inter-basin model for nodule growth, albeit with several inaccuracies. We list some of the essential requirements for the formation of nodules including the availability of nucleating materials, presence of metals in water column and sediment, favourable tectonic and physiographic features, helpful acoustically transparent sediment-water interface, low rate of sedimentation, presence of nutrient-rich bottom water mass and an oxidizing environment.

We present here an integrated assessment of process of formation of ferromanganese nodules from the IONF, which are variable even on scale of metres. This assessment will help evaluate the metal potential of these nodules more realistically, and the model should bring about a predictive estimate of other nodule bearing areas in the world oceans.
\end{abstract}

Key Words: Ferromanganese nodules, Indian Ocean Nodule Field, influencing parameters, Nodule formation and dynamics, Model of nodule formation. 


\section{Introduction}

The Central Indian Ocean Basin (CIOB) is located within the Indian Ocean and bordered by the Indian sub-continent on the north, and Ninety East Ridge and the Indian Ocean Ridge system on the other three sides. It is the largest and unique of all the basins in the Indian Ocean. Because of its complex tectonic fabric resulting from India's $5000 \mathrm{~km}$ migration of the Himalayas during the Cretaceous, and its abundance of ferromanganese nodules, this basin has long since attracted attention of oceanographers. The ferromanganese nodules are highly enriched in several elements compared to the continental crust (Table 1).

During the last three decades, the CIOB was explored in detail to delineate the location of economically viable nodule-bearing areas. These black, potato-shaped nodules (also known as ferromanganese deposits) occur at water depths ranging from 3000 to $6000 \mathrm{~m}$ in both nodular (average 2 to $8 \mathrm{~cm}$ diameters, Fig. 1) and encrustation forms. The nodular variety commonly occurs at the sediment-water interface, and varies in abundance from thinly scattered in some places to densely populate in other areas, often exceeding $10 \mathrm{~kg} / \mathrm{m}^{2}$.

The first phase of exploration during 1981-1987 included more than fifty oceanographic voyages to this basin to carry out reconnaissance survey, acquire bathymetry, gravity and magnetic data of the seafloor and collect samples of ferromanganese nodules and encrustations from the sea bottom. The second phase (1987-2000) involved close-grid exploration followed by a critical resource assessment to identify a possible mineable site. The amount and type of underway data collected during this period range from multi-beam bathymetry, to underwater photography and bulk sampling by net-dredge. A large number of ferromanganese nodules, rocks, sediment and water column samples was recovered. Critical investigation and research on the acquired data and samples helped delineate a nodule-rich area in the basin roughly bordered by $10^{\circ} \mathrm{S}$ to $16^{\circ} 30^{\prime} \mathrm{S}$ and $72^{\circ} \mathrm{E}$ to $80^{\circ} \mathrm{E}$. The area was named later as the Indian Ocean Nodule Field (IONF, Fig. 2, Mukhopadhyay et al., 2002).

The IONF represents the second largest and second richest deep-sea manganese nodule resource after that of the Equatorial North Pacific. A conservative estimate place the total manganese nodules availability in the IONF as more than 1400 million tons, with an average abundance of just over 4.5 kilogram per square meter $\left(\mathrm{kg} / \mathrm{m}^{2}\right)$. However, understanding the dynamics of nodule formation is a difficult task. In this paper, we restrict our study on nodules only as these are considered commercially more rewarding than the ferromanganese crusts, and examine the factors that influence dynamics of formation of the ferromanganese nodule deposits in the IONF. 


\section{Factors Influencing Nodule Formation}

The formation, distribution and composition of ferromanganese nodules vary from ocean to ocean, basin to basin, and even from place to place within a basin (Mukhopadhyay et al., 2008). It is therefore interesting to examine and model the various factors that might influence the formation, growth and characters of nodules in the neighbouring sectors within the IONF (sector A to D, Fig. 2). The seafloor underlying these sectors, originated from the Indian Ocean Ridge System (IORS), and is strikingly different from one sector to another. For example, the sectors $\mathrm{A}$ and $\mathrm{C}$ were formed during crustal stretching, and are characterised by a largely smooth seafloor, with the distribution of seamounts and volcanics ranging from zero in sector A to low to moderate in sector C. By contrast, the oceanic crusts in sectors B and D were generated during compressive regime as India was colliding with Eurasia during Palaeocene-Eocene period (Mukhopadhyay and Batiza, 1994). The seafloor in these two sectors appears disturbed, rough, undulating, faulted in places, and is characterized by high abundance of moderate to large seamounts and mid-plate volcanics (Table 2).

A close examination at seafloor conditions in the four sectors of the IONF (A, B, C, and D) reveals that the essential ingredients for the formation of ferromanganese nodules vary widely. These includes availability of nucleating materials, presence of metals in water column and sediment, favourable tectonic and physiographic features, favourable sediment-water interface, low rate of sedimentation, presence of nutrient-rich bottom water mass and an oxidizing environment. We have also established a commercially significant largely-held relation between morphology and composition of nodules from the IONF, e.g., high $\mathrm{Mn}, \mathrm{Cu}, \mathrm{Ni}$, and low $\mathrm{Fe}$, $\mathrm{Co}$ concentrations in smaller nodules, and the reverse in bigger nodules (Mukhopadhyay and Ramana, 1990). Similar findings have also been reported from Equatorial North Pacific (Friedrich et al., 1983). It appears that depending much on the local and regional factors, the nodule characters differ consistently and in a systematic pattern. We briefly discuss below some of these factors.

To initiate nodule growth, any solid object available on the ocean floor may serve as a potential nucleating agent (seed material) around which the concentric layers of ferromanganese oxide grow to form the nodule. An interesting positive relationship exists between nodule abundance (and distribution) and availability of seeds (e.g., fragments of rocks derived from seamounts, faults etc) in the IONF. Areas with large concentration of higher and larger seamounts, and good number of seafloor faults (both normal and reverse types), and showing signatures of crustal compression display very high nodule abundances attaining maximum of $13.73 \mathrm{~kg} / \mathrm{m}^{2}$ in sector D. By contrast 
areas, which show signs of tensional stress and have the least population of seamounts are characterized by least abundance of nodule (e.g., $1.83 \mathrm{~kg} / \mathrm{m}^{2}$ in sector A).

The element enrichment in nodules appear to be largely controlled by the process of diagenesis (Glasby, 2000). For diagenesis, the viscosity and thickness of the upper sediment layer, also known as acoustically transparent sediment layer (ATSL), occurring between seawater and semi-consolidated sediment at the seafloor plays an important role (Usui et al., 1987; Mukhopadhyay and Nath, 1988). Our study confirms earlier suggestions (cf. Mukhopadhyay et al., 2008, Jauhari and Pattan, 2000) that the degree of diagenetic mobilisation of elements forming the nodules essentially depends on the rate of sedimentation and temperature gradient within the ATSL. For example, the degree of remobilisation of metals within sediment, and the rate of upward diffusion of dissolved elements from the sediment to the sediment-water interface of ATSL depend entirely on the Eh-pH status within the ATSL (i.e., the oxidation potential of the overlying water column). In some parts of the IONF, a moderate to high degree of metal contribution from the underlying sediment into the nodule by the process of diagenesis through the ATSL was also recorded. The ATSL is thinnest in sector D $(\sim 6 \mathrm{~m})$, and thickest in sector A ( $20 \mathrm{~m})$, with an average thickness of $17 \mathrm{~m}$ in sector B and $10 \mathrm{~m}$ in sector C.

A majority of the nucleating rock fragments in the IONF surfaced during late Miocene volcanism. The precipitation of ferromanganese oxides was initiated around these nucleating materials probably between 8 and 3 million years ago (Ghosh and Mukhopadhyay, 1995). Considering the slow rate of accretion of deep-sea nodules (few $\mathrm{mm}$ in million years), the rapid mixing time of manganese in oceans (c. $1000 \mathrm{yr}$ ) and short half-life of iron precipitation (i.e., 2-3 minutes), it is possible to infer that metal-flux from the local in-situ eruptions (Iyer et al., 1997) played a role. We found evidence (Mukhopadhyay et al., 2002) to suggest that the metal flux from such secondary eruptions influenced the grade of nodules, by supplying metals to the water column for hydrogenous precipitation and to the bottom sediment for later accretion through diagenesis.

As nodule formation requires undisturbed bottom conditions, a low sedimentation regime (Piper and Williamson, 1977), low bottom water currents (Glasby et al., 1982), the formation of nodules is supported by the abundance of aerobic/anaerobic bacteria (Das et al., 2005). It is important to note that the equatorial part of the CIOB is practically devoid of nodules, which may well be due to higher rate of terrigenous sedimentation thereby inhibiting nodule growth. However, the high $\mathrm{Mn} / \mathrm{Fe}$ ratio in these nodules is related to the high productivity of water column. This would suggest that sedimentation rates influence the nodule distribution, morphology and composition. 
Identifying the source of elements for the formation of nodules in the IONF has been one of the most difficult tasks. However, the indicative source of elements (not exhaustive) for the formation of IONF nodules may include, in order of dominance- (a) continental weathering (elements transported by rivers and other drainage systems), (b) submarine volcanism (low temperature hydrothermal solutions or volcanic exhalations), (c) weathering (halmyrolysis, i.e., elements released through alteration of basalts and transported in dissolved state, and (d) cosmic material (with increased sedimentation of cosmic spherules).

\section{Model of nodule formation}

Among the local and regional environments that influence the various characteristics of IONF nodules, we focus on the three major factors - (a) availability of seeds/ nucleating agents, (b) seafloor characteristics, and (c) source of metals. Various combinations of these three parameters can be modelled to examine the formation of nodules. Although seamounts, large faults and fracture zones are generally responsible for supply of rock fragment as nuclei / seeds for the formation of nodule, the nature of bottom sediment (ATSL), sediment type, biological productivity, secondary eruption and low rate of sedimentation play significant roles in influencing the composition of ferromanganese nodules (Fig. 2).

The growth and enrichment of nodules is generally facilitated by enhanced metal supply from the water column, and a substratum favouring diagenetic process for element mobilisation and incorporation. The enrichment sequence for divalent metals in the nodules through diagenetic process compared to the hydrogenetic one is $\mathrm{Cu}>\mathrm{Ni}>\mathrm{Zn}>\mathrm{Mo} \sim \mathrm{Mn}>\mathrm{Ti} \sim \mathrm{Ba}$ (Friedrich et al., 1983). We have reconstructed conditions that probably existed during the last $10 \mathrm{Ma}$ (the age of the IONF nodules is less than $10 \mathrm{Ma}$ ). Although siliceous clay and ooze floor all the sectors within the IONF (except perhaps the southernmost part of sector D), the influence of detrital sedimentation, and consequently the rate of sedimentation, increases towards north (sectors A and part of B). The siliceous sediment is found to be the most favourable substratum for nodule growth, as its high porosity facilitates the upward diffusion of elements through the sediment column. However, the availability of seeds to form nodules is limited in sectors A and B, as most of the tectonic activities (which supplies seeds) and intraplate secondary volcanism (which supplies both metal and seeds) are concentrated in the south (sectors C and D). The sedimentation rate in the IONF decreases from 9 $\mathrm{mm} / \mathrm{ka}$ in its northern part to $1 \mathrm{~mm} / \mathrm{ka}$ to the south (Borole, 1993). In addition, the degree of biological productivity is also enhanced towards the north. 
Table 2 shows the properties of ferromanganese nodules and various formative environments in the IONF. In fact, the underlying crust of sector A was formed prior to $58 \mathrm{Ma}$, when the crust was forming from the mid-oceanic ridge at high rate ( $\sim 90 \mathrm{~mm} / \mathrm{year}$, half rate), resulting in extreme stretching and least compression of the lithosphere (Fig. 2). In this sector, the nodules display thick oxide layer (nucleus: oxide ratio is 0.57 ), high $\mathrm{Mn} / \mathrm{Fe}$ ratio and high metal grade $(\mathrm{Cu}+\mathrm{Ni}+\mathrm{Co}=2.89 \%)$. A relatively thick ATSL $(\sim 20 \mathrm{~m})$ and comparatively high biological productivity in this sector further help contribute metals to the nodules through both hydrogenetic and diagenetic processes. The sector A, however, records high sedimentation rate, many times more than the growth rate of nodules (1.2 $3.2 \mathrm{~mm} / \mathrm{Ma}$, Banakar, 1990) and host very low abundance of tectonic (fault and fold) or volcanic (seamount, secondary eruption) activities. These may have been the reason for an extremely low abundance of nodules in this sector.

The sectors $\mathrm{B}$ and $\mathrm{C}$ display moderate to low biological productivity, low sedimentation rate but substantial concentrations of intraplate volcanic activities. This unique situation is reflected with an increase in abundance of nodules. The presence of many closely spaced south facing reverse faults in sectors B and C suggests crustal deformation and release of stress through the deformed fault planes. Such deformation-stress may have opened up several sealed conduits for the sub-surface trapped magma to ascend. The resulting secondary eruption (some as young as $10 \mathrm{ka}$ ) was likely to contribute rock fragments as seed material, and released elements to the seawater. Such a regime characterized by high abundance of seeds and high concentration of elements had certainly increased the population and enriched the grade of the nodules through both hydrogenetic and diagenetic processes. The formation of nodules in sectors $\mathrm{B}$ and $\mathrm{C}$ and their enrichment in $\mathrm{Mn}, \mathrm{Cu}$ and $\mathrm{Ni}$, in particular, appear also to be partially contributed by elements from sediment interstitial water. Leaching of elements from the bottom sediment by interstitial water, warmed by sub-surface igneous activities caused diffusion of elements (largely $\mathrm{Mn}, \mathrm{Cu}, \mathrm{Ni}$ ) to the sediment-water interface. These elements, in turn, may ultimately get incorporated into the nodules through diagenesis. Mineralogy and composition of ferromanganese nodules formed through three possible methods are shown in Table 3 .

As discussed, the upward diffusion of element-laden interstitial water and discharge of elements ultimately at the sediment-water interface are facilitated by various physico-chemical conditions. When the concentration and temperature gradient at this interface (i.e., within the ATSL) become steep, and when the oxidation potential (Eh) of overlying seawater is high relative to the interstitial water, rapid precipitation of $\mathrm{Mn}, \mathrm{Cu}$ and Ni occurs. The igneous activities / intrusive within the sediment in sectors $\mathrm{B}$ and $\mathrm{C}$ could provide the required energy to extract and transport metals from the interstitial pore 
spaces to the seafloor. So, the diagenetic contribution of metals to the nodules of sectors B and C takes place in addition to that obtained predominantly through hydrogenesis (Fig. 2).

In sector $\mathrm{D}$, an extremely low sedimentation rate $(\sim 1 \mathrm{~mm} / \mathrm{ka})$ and increased occurrence of south facing reverse faults (51\%) could be responsible for high abundance of nodules $\left(5.82 \mathrm{~kg} / \mathrm{m}^{2}\right.$, Table 2). The faults may have originally been north facing normal faults, which were transformed to reverse fault under large-scale tectonic compression. There have been very few intraplate volcanic activities in this sector. The biological productivity, as also the thickness of the ATSL is extremely low in sector D. The absence of igneous activities in the subsurface layers of this sector, coupled with other unfavourable seafloor conditions for metal accumulation, as described above, may account for reasonably low diagenetic contribution to the nodules in this sector. Such a situation is responsible for the formation of nodule deposits of relatively low grade.

In summary, it is evident that optimum and positive combination of various impacting parameters are important for nodule growth in the IONF. Elements may be seawater-derived as well as sediment-derived, the relative dominance of a particular source being indicated by the $\mathrm{Mn} / \mathrm{Fe}$ ratios. Also, contribution of seawater and interstitial water to a large extent influences the trend of metal enrichment in nodule, as well as nodule mineralogy. The dynamics of nodule formation modelled above may appear applicable to other oceanic basins.

\section{Acknowledgements}

The research was carried out under the WIOPET project. The manganese nodules and related data were acquired during India's deep-sea campaign for minerals, supported by the Ministry of Earth Sciences, New Delhi. We thank GP Glasby and another reviewer for helpful reviews. This is NIO contribution 5312 . 


\section{References}

Banakar, V. K., 1990. Uranium-thorium isotopes and transition metal fluxes in two oriented manganese nodules from the Central Indian Basin: Implications for nodule turnover. Marine Geology 95, 71-77.

Borole, D. V., 1993. Late Pleistocene sedimentation: A case study in the Central Indian Ocean Basin. Deep-Sea Research 40, 761-775.

Burns, R. G., Burns, V. M., 1977. Mineralogy. In: Glasby, G.P. (Ed), Marine Manganese Deposits. Elsevier, Amsterdam, pp. 185-248.

Das, A., Fernandes, C.E.G., Naik, S.S., Nath, B.N., Loka Bharathi, P.A., 2005. Bacterial response to contrasting geochemistry in the sediments of Central Indian Ocean Basin. In: Anand, S., Sanjay, K.(Eds.), Proceedings of National Seminar on Polymetallic Nodules, RRL (IMMT), Bhubaneshwar, pp. 1-8.

Friedrich, G., Glasby, G. P., Thijssen, T., Pluger, W. L., 1983. Morphological and geochemical characteristics of manganese nodules collected from three areas on an equatorial Pacific transect by R. V. Sonne. Marine Mining 4, 167-254.

Ghosh, A. K., Mukhopadhyay, R. (1995). Large phillipsite crystal as ferromanganese nodule nucleus. Geo-Marine Letters 15, 59-62.

Ghosh, A. K., Mukhopadhyay, R., 1999. Mineral Wealth of the Ocean. AA. Balkema, Rotterdam, 260 p. and Oxford \& IBH Publication, New Delhi, 266p.

Glasby, G. P., 2000. Lesson learned from deep-sea mining. Science 289, 551-553.

Glasby, G. P., Friedrich, G., Thijssen, T., Pluger, W. L., Kunzendorf, H., Ghosh, A. K., Roonwal, G. S., 1982. Distribution, morphology and geochemistry of manganese nodules from the Valdivia 13/2 area, equatorial north Pacific. Pacific Science 36, 241-263.

Halbach, P., Özkara, M., 1979. Morphological and geochemical classification of deep-sea ferromanganese nodules and its genetic interpretation. In: La Genese des Nodules de Manganese, Colloquies Institute CNRS, Paris, vol. 289, pp. 77-88.

Iyer, S. D., Prasad, M. S., Gupta, S. M., Charan, S. N., 1997. Evidence for recent hydrothermal activity in the Central Indian Basin. Deep-Sea Research 44, 1167-1184.

Jauhari, P., Pattan, J. N., 2000. Ferromanganese deposits in the Indian Ocean. In: Cronan, D.S. (Ed.), Handbook of Marine Mineral Deposits, CRC Publications, NY pp. 171-195.

Mero, J. L., 1965. The Mineral Resources of the Sea. Elsevier, Amsterdam, 312 p. 
Mukhopadhyay, R., Batiza, R., 1994. Basinal seamounts and seamount chains of the Central Indian Ocean: Probable near axis origin from a fast spreading ridge. Marine Geophysical Research 16, 303314.

Mukhopadhyay, R., Nath, B. N., 1988. Influence of seamount topography on the local facies variation in ferromanganese deposits in the Indian Ocean. Deep-Sea Research 35, 1431-1436.

Mukhopadhyay, R., Ramana, Y. V., 1990. Acoustic properties of Indian Ocean manganese nodules in relation to physical constitution and chemical composition. Deep-Sea Research 37, 337-342.

Mukhopadhyay, R., Iyer, S. D., Ghosh, A. K., 2002. The Indian Ocean nodule field: Petrotectonic evolution and ferromanganese deposits. Earth Science Review 60, 67-130.

Mukhopadhyay, R, Ghosh, AK, Iyer S.D., 2008. The Indian Ocean Nodule Field: Geology and Resource potential. Elsevier, Amsterdam, 292+xiiip.

Piper, D.Z., Williamson, M.E., 1977. Composition of Pacific Ocean ferromanganese nodules. Marine Geology, 23, 285-303.

Usui, A., Nishimura, A., Tanahashi, M., Terashima, S., 1987. Local variability of manganese nodules facies on small abyssal hills of the Central Pacific Basin. Marine Geology 74, 237-275. 
Tables

Table 1. Element enrichment in ferromanganese nodules relative to continental crust

\begin{tabular}{llll}
\hline Element $(\%)$ & $\begin{array}{l}\text { Abundance in } \\
\text { Oceanic nodules }\end{array}$ & $\begin{array}{l}\text { Crustal } \\
\text { abundance }\end{array}$ & $\begin{array}{l}\text { Enrichment } \\
\text { factor }\end{array}$ \\
$\mathrm{Mn}$ & 16.02 & 0.095 & 169 \\
$\mathrm{Fe}$ & 15.55 & 5.6 & 2.8 \\
$\mathrm{Ni}$ & 0.48 & 0.0075 & 64 \\
$\mathrm{Co}$ & 0.28 & 0.0025 & 114 \\
$\mathrm{Cu}$ & 0.26 & 0.0055 & 47 \\
$\mathrm{Mo}$ & 0.041 & 0.00015 & 275 \\
$\mathrm{~V}$ & 0.056 & 0.0135 & 4.1 \\
$\mathrm{Ti}$ & 0.647 & 0.570 & 1.1 \\
\hline
\end{tabular}

(Adopted from Mukhopadhyay et al., 2008) 
Table 2. Nodule characteristics in various sectors of IONF

Sector A Sector B Sector C Sector D

Abundance $\left(\mathrm{kg} / \mathrm{m}^{2}\right)$

$\begin{array}{lllll}\text { Maximum } & 8.72 & 12.69 & 18.79 & 13.73 \\ \text { Average } & 1.83 & 4.12 & 5.34 & 5.82\end{array}$

\section{Composition (\%)}

$\begin{array}{lcccc}\mathrm{Mn} & 24.50 & 24.20 & 25.33 & 24.10 \\ \mathrm{Ni} & 1.39 & 1.18 & 1.22 & 0.99 \\ \mathrm{Cu} & 1.41 & 1.11 & 1.29 & 1.19 \\ \mathrm{Co} & 0.09 & 0.11 & 0.13 & 0.13 \\ \mathrm{Ni}+\mathrm{Cu}+\mathrm{Co} & 2.89 & 2.40 & 2.64 & 2.31\end{array}$

Intraplate Volcanism

$\begin{array}{llccr}\text { Abundance } / 10^{6} \mathrm{~km}^{2} & 00 & 2403 & 1263 & 900 \\ \text { Seamounts }>500 \mathrm{~m} / 10^{6} \mathrm{~km}^{2} & 00 & 449 & 276 & 509\end{array}$

\section{Seafloor Roughness}

\begin{tabular}{lcccc} 
Fault (population $/ 10^{6} \mathrm{~km}^{2}$ ) & 759 & 1079 & 867 & 1164 \\
Normal : Reverse faults & 00 & 1.32 & 2.84 & 1.04 \\
ATSL (m) & $\sim 20$ & 17 & 10 & 06 \\
& & & & \\
\hline
\end{tabular}

Source: Jauhari and Pattan (2000), Mukhopadhyay et al. (2002). ATSL= acoustically transparent sediment layer 
Table 3. Modes of formation and average composition nodules in the IONF.

$\begin{array}{llll}\text { Nodule Type } & \text { A } & \text { B } & \text { AB }\end{array}$

\begin{tabular}{llcc} 
Source of Metals & $\begin{array}{l}\text { Interstitial } \\
\text { water }\end{array}$ & $\begin{array}{c}\text { Near-bottom } \\
\text { \& bottom water }\end{array}$ & $\begin{array}{c}\text { Both interstitial wat } \\
\text { Major Mineral }\end{array}$ \\
Todorokite & Birnessite & $\begin{array}{l}\delta \text { - } \mathrm{MnO}_{2} \\
\text { (Vernadite) }\end{array}$ \\
Growth mechanism & Early digenetic & Hydrogenetic & Mixed \\
Composition: & 27.22 & 20.97 & 24.16 \\
$\mathrm{Mn}$ & 5.70 & 11.48 & 7.69 \\
$\mathrm{Fe}$ & 0.12 & 0.19 & 0.14 \\
$\mathrm{Co}$ & 1.31 & 1.21 & 1.21 \\
$\mathrm{Ni}$ & 1.39 & 1.13 & 1.13 \\
$\mathrm{Cu}$ & 4.77 & 1.83 & 3.14 \\
$\mathrm{Mn} / \mathrm{Fe}$ & & & \\
\hline
\end{tabular}

Source: Burns and Burns (1977), Halbach and Özkara (1979), Ghosh and Mukhopadhyay (1999). 


\section{Caption to the Figures}

Fig. 1. Morphological variations of ferromanganese nodules in the IONF. Rough surface nodule with large round globe-like mammilla at the centre surrounded by organic matter in white (top-left), rough surface nodule with largely regular outline (top-right), cracks developed on the surface of an ellipsoidal nodule (below-left) and growing oxide precipitation at one corner of shark tooth (below-right). Mostly fragments of rocks, broken pieces of old nodules and altered clay-stones and shark tooth are found as nucleus.

Fig. 2. The IONF comprises four sectors- A to D. The underlying crust was formed between 60 and 49 Ma- the oldest crust formed in the north. The crust lying below sectors A and C was generated at a faster rate, while the crust below sectors B and D was accreted through a slow process of crustal generation from the Indian Ocean Ridge system. The bottom of the sectors $\mathrm{B}$ and $\mathrm{C}$ are covered by siliceous sediment, while the sectors $\mathrm{A}$ and D are floored by a mixture of siliceous \& terrigenous, and siliceous \& pelagic/red clay, respectively. The major components that influence nodule formation in four sectors are listed in the boxes. An optimum balance among these parameters would ensure an efficient grade (GR) and substantial abundance $(\mathrm{AB})$ of nodule resources (see text for details).

$\mathrm{CIR}=$ Central Indian Ridge, SWIR $=$ Southwest Indian Ridge, SEIR $=$ Southeast Indian Ridge, $\mathrm{CLR}=$ Chagos-Laccadive Ridge, $\mathrm{IAPB}=$ Diffused and deformed plate boundary between India and Australia (hatched zone), TJT-In= Trace of the Junction of Triple ridgesSWIR, CIR and SEIR- on the Indian Plate, north-south dashes are fracture zones (FZ), and horizontal dashes are magnetic anomalies with number. ST= sediment type ( $\mathrm{S}=$ siliceous, $\mathrm{P}=$ pelagic, $\mathrm{T}=$ terrigenous, and porosity), $\mathrm{AT}=$ acoustically transparent sediment layer $(\mathrm{m})$, $\mathrm{RG}=$ seafloor roughness, $\mathrm{SM}=$ seamount population, $\mathrm{SP}=$ secondary eruptions (adopted from Mukhopadhyay et al., 2002). 


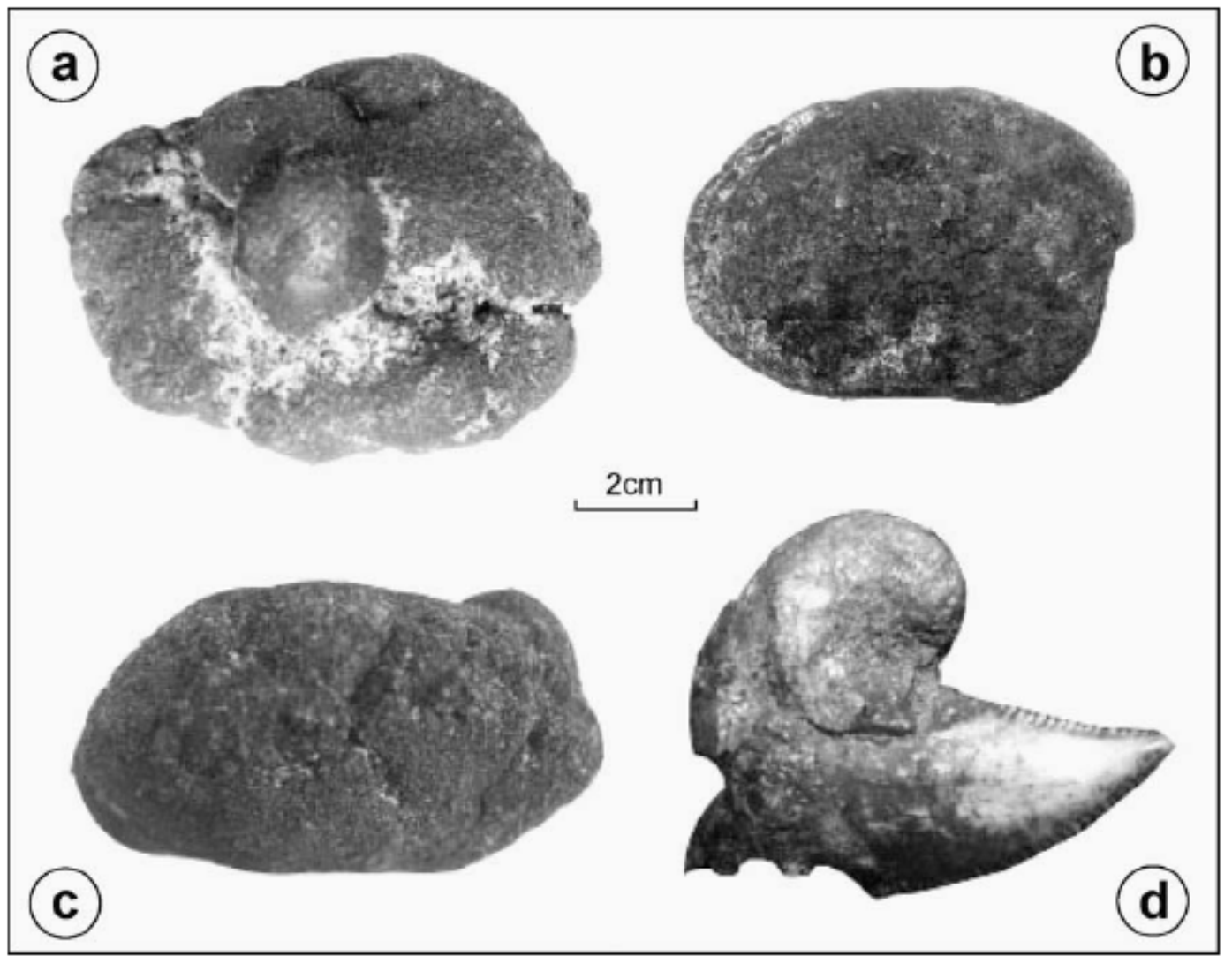




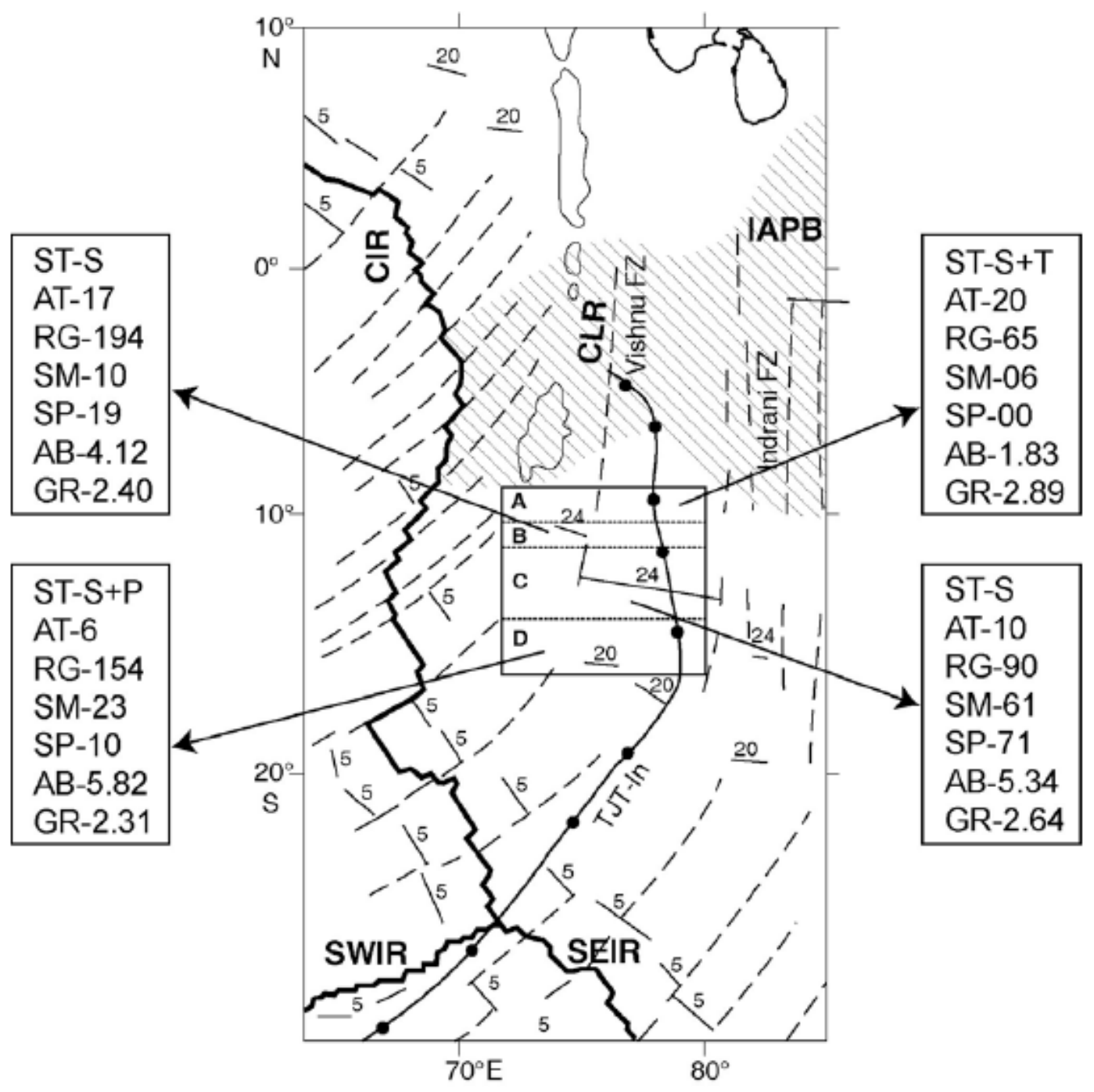

